\title{
Ex situ conservation of threatened plants in Brazil: a strategic plan to achieve Target 8 of the Global Strategy for Plant Conservation
}

\author{
Fernando A.O. Silveira ${ }^{1,4}$, Alberto L. Teixido ${ }^{1}$, Marcílio Zanetti ${ }^{1}$, Juliano Gomes Pádua ${ }^{2}$, \\ Antônio Carlos Silva de Andrade ${ }^{3}$ \& Maria Lúcia Nova da Costa ${ }^{3}$
}

\begin{abstract}
With increasing rates of habitat destruction and species loss, ex situ conservation is gaining global momentum and reluctance in relying on ex situ conservation is rapidly giving way to a more optimistic, strategic view. Target 8 of the Global Strategy of Plant Conservation calls for at least 75 percent of threatened plant species in accessible ex situ collections, preferably in the country of origin, and 20 percent of them included in recovery and restoration programs. Here, we provide updated information on Brazil's progress towards Target 8 through a nationwide examination of how many threatened species were conserved in ex situ collections in Brazil. Our data comprised whole plants (living collections), seed (seed banks) and tissue cultures (in vitro). Of the 2,113 threatened species, at least $452(21.4 \%)$ species were conserved in ex situ collections, an increase in $4 \%$ of living organisms and $96 \%$ of seeds when compared to a previous assessment. Since it is unlikely Brazil will achieve Target 8 by 2020, we also discuss public policies and strategies to help overcome key bottlenecks preventing its achievement and propose revised goals for the GSPC 2020-2030.

Key words: botanic gardens, conservation policy, GSPC, living collection, seed conservation, seed bank.

\section{Resumo}

Com as crescentes taxas de destruição de habitats e perda de espécies, a conservação ex situ vem ganhando ímpeto global e a relutância de se depender da conservação ex situ vem rapidamente dando lugar a uma visão mais otimista e estratégica. A Meta 8 da Estratégia Global de Conservação de Plantas prevê a incorporação de pelo menos $75 \%$ de espécies ameaçadas em coleções ex situ, preferencialmente no país de origem e $20 \%$ delas disponíveis para programas de restauração ecológica. Nós fornecemos informações atualizadas sobre o progresso brasileiro sobre a Meta 8 através de uma investigação sobre quantas espécies ameaçadas estão conservadas em coleções ex situ no Brasil. Nossa base de dados compreende plantas inteiras (coleções vivas), sementes (banco de sementes) e cultura de tecidos (in vitro). Das 2,113 espécies ameaçadas, pelo menos 452 (21.4\%) espécies estão conservadas em coleções ex situ, um aumento de 4\% para coleções vivas e 96\% para sementes comparado com avaliações anteriores. Como é improvável que o Brasil vá atingir a Meta 8 até 2020, nós discutimos políticas públicas e estratégias para ajudar a superar os obstáculos que impedem a sua realização e propomos metas revisadas para a GSPC 2020-2030.

Palavras-chave: jardins botânicos, política de conservação, EGCP, coleções vivas, conservação de sementes, banco de sementes
\end{abstract}

\section{Introduction}

Plants are widely recognized as a pivotal component of the world's biodiversity and an essential resource for mankind. In addition to the plant species used for food, timber, medicines and fibers, many wild species have great economic, cultural and religious importance as future crops and commodities. Plants play a key role in maintaining the planet's environmental balance and ecosystem multifunctionality and provide an irreplaceable component of the habitats for the world's animal life (CBD 2010, decision X/17).

\footnotetext{
${ }^{1}$ Universidade Federal de Minas Gerais, Depto. Botânica, Av. Antônio Carlos 6627, 30161-970, Belo Horizonte, MG, Brazil.

${ }^{2}$ EMBRAPA, Recursos Genéticos e Biotecnologia, PqEB, Av. W5 Norte (final), 70770-917, Brasília, DF, Brazil.

${ }^{3}$ Instituto de Pesquisas Jardim Botânico do Rio de Janeiro, R. Pacheco Leão 915, Jardim Botânico, 22460-030, Rio de Janeiro, RJ, Brazil.

${ }^{4}$ Author for correspondence: faosilveira@icb.ufmg.br
} 
Nevertheless, the survival of plant species and the ecosystem services they provide are both locally and globally threatened by anthropogenic activities (Heywood 2017; Pimm \& Raven 2017), which resulted in the development of the Global Strategy for Plant Conservation (GSPC).

The GSPC is a global effort aiming to document, conserve and use sustainably plant diversity, as well as increasing awareness about plant diversity, capacitate and engage public to implement the 16 outcome-oriented targets by 2020 (CBD 2010, decision X/17). The rationale behind the 16 targets is that once the GSPC is put into practice, human societies will be able to secure essential ecosystem services (including food and energy security, use the potential of plants to mitigate and adapt to climate change, reduce the risk of plant extinction, explore the rich evolutionary legacy of plant diversity and increase awareness of the urgency of plant conservation (CBD 2010, decision X/17).

The original Target 8 of GSPC from 2002 called for 60 percent of threatened plant species in accessible ex situ collections, preferably in the country of origin, and 10 percent of them included in recovery and restoration programs. The revised Target in 2010 presently calls for at least 75 percent of threatened plant species to be included in ex situ collections, preferably in the country of origin, and at least 20 percent available for recovery and restoration programs.

The recent mid-term document reports good global progress made towards Target $8(<\mathrm{https}$ :// www.cbd.int/doc/meetings/sbi/sbi-01/information/ sbi-01-inf-32-en.pdf $>$ ). However, the mid-term report does not address the Brazilian progress towards Target 8 . Two independent publications have recently assessed the Brazilian progress of the two major ex situ conservation strategies: living collections (Costa et al. 2017) and seed banking (Teixido et al. 2017). Unfortunately, information was not integrated between these studies, hence preventing any attempts of a nationwide Brazilian assessment of the progress towards Target 8 . Here, we address the history, progress and future perspectives of Target 8 in Brazil by integrating data of threatened species in ex situ collections. Particularly, we 1) provide updated information on the progress of Target 8 through a nationwide consultation; 2) report the results of a web-based poll to estimate the conservation capacity in the country and to survey hurdles underlying the efforts for Target
8 implementation; 3) discuss public policies and strategies to overcome key bottlenecks preventing Target 8 achievement; and 4) propose revised goals for the GSPC 2020-2030.

Strategies for in situ conservation have long been the focus of biodiversity conservation worldwide. As a result of such historical developments, there is now international agreement that allocating particular parts of Earth to support biodiversity should be enough to achieve GSPC targets (Joppa et al. 2013; Watson \& Venter 2017). However, owing to increasingly disappearing of natural habitats, and constantly growth in the number of imperiled plants, ex situ conservation has gained global momentum (Volis 2017; Liu et al. 2018). Ex situ conservation was defined in Article 2 of the Convention on Biological Diversity (CBD) (UNCED 1992) as "the conservation of components of biological diversity outside their natural habitats." It involves the sampling, transference, and storage of target taxa from the collecting area and is generally used to safeguard species or populations that are at present or are potentially in danger of physical destruction, replacement, or genetic deterioration. The techniques for ex situ conservation currently used include seed (and spore) banks, field gene banks, in vitro storage, pollen banks, DNA storage, and living plants in botanic gardens (Hawkes et al. 2000; Pellegrini \& Balatti 2016; O'Donnell \& Sharrock 2017; Fig. 1). Botanic gardens and other ex situ facilities, and particularly seed banks are among the most extensive plant conservation resources in the world. Ex situ conservation is a safe, relevant, multipurpose and cost-effective way of preserving species and genetic diversity, and at the same time increase awareness of biodiversity. Ex situ collections can provide germplasm that can be reintroduced to

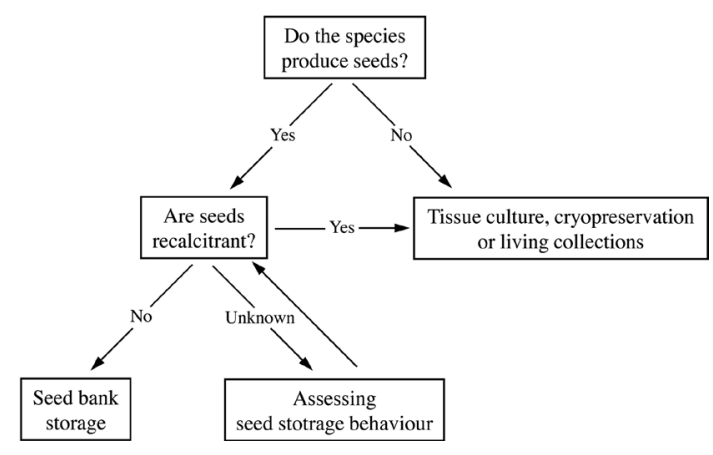

Figure 1 - Workflow of species traits needed to be addressed to orient the best ex situ conservation strategy. 
their original or, where necessary, ecologically restored habitats (Cochrane et al. 2007). However, misconceptions and misperceptions of ex situ have prevented conservation biologists to recognize its potential and complementary roles in conservation (Guerrant et al. 2004).

Ex situ conservation also plays roles that are not fulfilled by in situ conservation. Such goals include conservation of species extinct in the wild (Oldfield 2009) and insurance against natural and anthropogenic threats to plants in situ (pollution, wars, political conflicts, dam bursts, etc; O'Donnell \& Sharrock 2017). Ex situ conservation may be the only feasible strategy for species that will inevitably experience partial or full in situ loss of populations. Furthermore, costs of ex situ conservation are relatively low, and species can be conserved for hundreds of years in a relatively small place (Li \& Pritchard 2009; O'Donnell \& Sharrock 2017). To date, more than a third of plant taxa are represented in botanic garden collections (Mounce et al. 2017), showing the realized potential and relevance of ex situ collections.

\section{Material and Methods}

To monitor the Progress in implementation of GSPC's Target 8 in Brazil, we provide an updated list of threatened species in living collections (Costa et al. 2017, 2018) and seed banks (Teixido et al. 2017) based on a survey with 21 botanic gardens registered in the Brazilian Ministry of the Environment (MMA) and other Brazilian plant conservation institutions (Brazilian Agricultural Research Corporation and Instituto Florestal).

To estimate conservation capacity, we launched an online survey ( $<$ https://goo.gl/forms/ smjijRJ56rRgjvn93 $>$ ) on August 6, 2017 that was advertised in social media, scientific societies, scientific meetings and the Brazilian Botanic Gardens Network. The survey was closed on December 18, 2017. The goal of the survey was to evaluate the conservation capacity of the country and the awareness of the conservation community towards the GSPC Target 8 . Most (>78\%) of the 75 respondents from 52 institutions were biologists and agronomists with skilled experience (68\% hold a Ph.D title) in research and teaching. A high percentage $(77 \%)$ of respondents work on seed ecophysiology focused on ex situ conservation and ecological restoration, but there was a strong bias towards species from the Atlantic Forest (53\%) and the Cerrado (47\%).

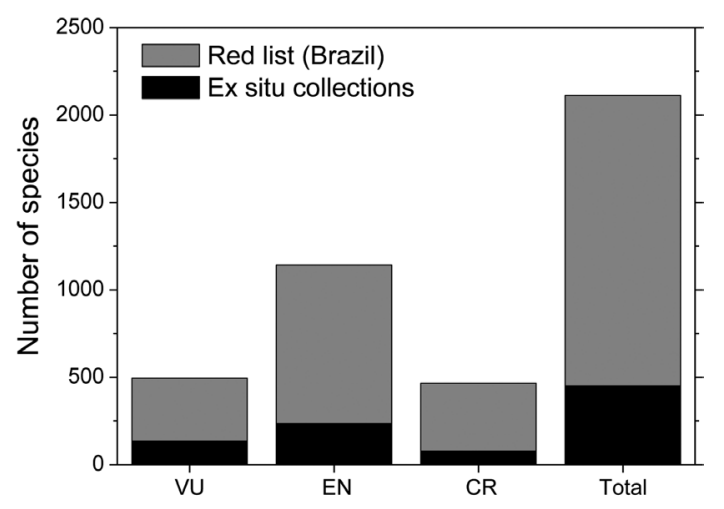

Figure 2 - Distribution of the 452 ex situ conserved (black columns) species and total number of the Brazilian Red List (grey columns) by threat category. (VU = vulnerable; $\mathrm{EN}=$ endangered; $\mathrm{CR}=$ critically endangered; $\mathrm{NE}=$ not evaluated).

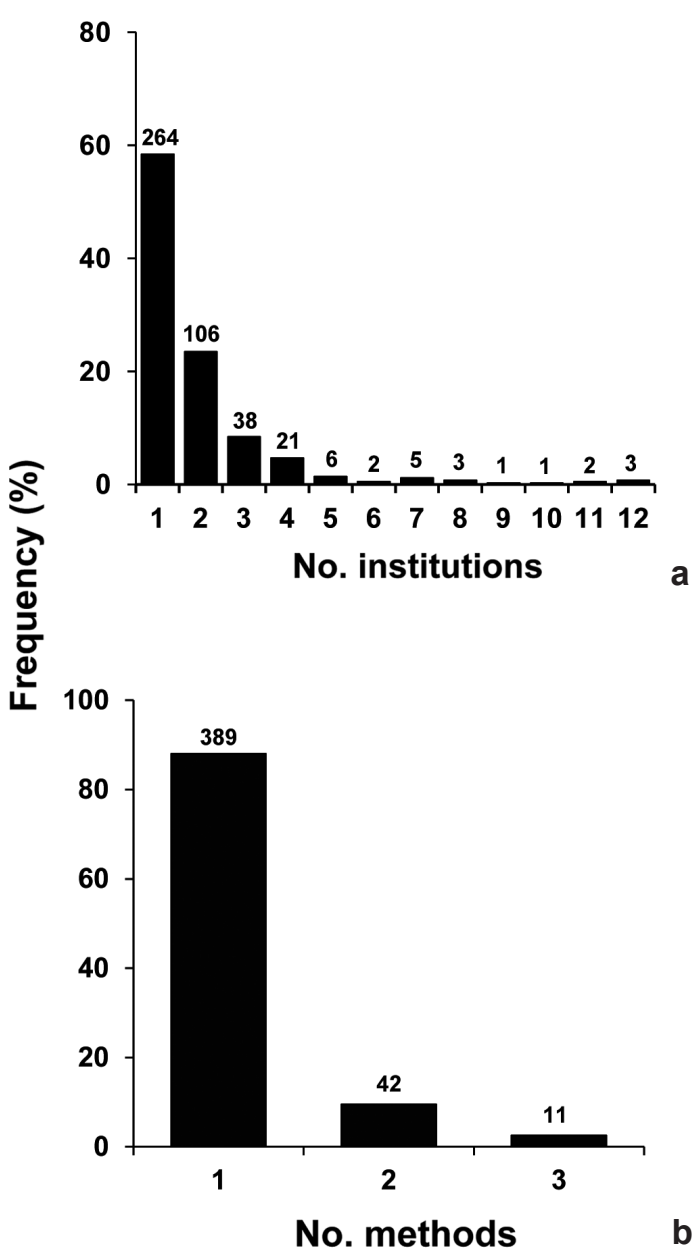

Figure 3-a,b. Percentage of ex situ conserved threatened species $-a$. based on the number of accessions; $b$. based on the number of ex situ conservation methods. Absolute number of species are shown above each bar. 


\section{Results and Discussion}

We found 452 species conserved ex situ or $21 \%$ of the Brazilian Red List (Brasil 2014), with 440 species conserved in arboreta or greenhouses, 52 species in seed banks, 18 species in field banks and eight species conserved in vitro [Table S1 (<https://doi.org/10.6084/m9.figshare.7199750.v2>)]. The distribution of these 452 species according threat category was as following: 53\% Endangered, $30 \%$ Vulnerable and 17\% Critically Endangered (Fig. 2). Nearly $60 \%$ of the ex situ conserved species had only one institution, and only six $(1.3 \%)$ species had more than 10 institutions (Fig. $3 a)$. Nearly $86 \%$ of the species were conserved through a single method, and only eleven species $(2.4 \%)$ were conserved by three ex situ methods (Fig. 3b).

The great majority of plants were conserved in living collections of botanic gardens where the species in field banks were maintained by agricultural and forestry institutions. The number of Brazilian threatened species conserved ex situ in living collections and in seed banks has increased four percent and 96 percent, respectively, in the database (Costa et al. 2017; Teixido et al. 2017). The results revealed some very valuable collections but the majority of species in living collections raise the concern regarding deficiencies in genetic diversity of collections.

Despite recent improvements, ex situ conservation of threatened species is still an overlooked issue in Brazil. This situation compromises the international conservation commitments signed to achieve the Target 8 during the remaining two-year period. Our results may have slightly underestimated ex situ conservation in Brazil, since some institutions did not participate in the survey and three botanic gardens did not reply to our demand. Unfortunately, the inexistence of an integrated database to compile and provide available information of plant collections hinders a more comprehensive assessment.

Our results showed significant knowledge gaps in ex situ conservation [Table S2 (<https://doi. org/10.6084/m9.figshare.7199750.v2>)]. Nearly $75 \%$ of respondents declared to have worked with seed conservation in native species. Unexpectedly however, only half of respondents (38\%) were aware of the GSPC Target 8. For example, 40\% of researchers had never incorporated accessions to seed banks despite having worked with seed conservation in hundreds of species. Half of the respondents found unlikely that Brazil will achieve the Target by 2020 , whereas only $13.5 \%$ thought it is possible to meet the challenge by 2020 . Nearly $80 \%$ of respondents found the status of seed conservation is bad/very bad (unsatisfactory) and $64 \%$ found the status of science outreach of seed conservation to be bad/very bad. Additionally, over half of respondents was not aware of the economic costs associated to seed banking. Indeed, the survey revealed that between $60-70 \%$ of the respondents thought that seed conservation status and knowledge transfer were neglected, especially due to lack of economic and human resources, infrastructures and policy coordination.

Relative to the question about the strategies to improve the current scenario of ex situ plant conservation in Brazil, only 57\% of respondents expressed any suggestion. Overall, four main issues were raised to pursue the achievement of the Target by 2020: (1) to prompt a coordinated effort between government and the scientific community that boosts further research, international partnerships and public policies; (2) to enhance the cooperation and communication among national conservation institutions to enable data access and sharing; (3) to increase the economic and human investment in order to upgrade the number and quality of accessions in seed banks, mainly in underrepresented biomes; and (4) to prioritize the collection of species in relation to their occurrence and threatened status, decentralizing the sampling and storage efforts through the national territory.

Brazil harbors the highest number of seedbearing species and endemism in the world (Forzza et al. 2012; Brazilian Flora 2020), and it currently plays an international leading role in environmental conservation (Scarano et al. 2012; Crouzeilles et al. 2017). However, ex situ conservation requires a structured nationwide strategy coordinated by government agencies, policy makers and research institutions.

Target 8 is likely the most difficult GSPC target to achieve due to the time-consuming, experimental work needed to conserve species. Information on species physiology including knowledge on seed biology (production, dormancy, germination, storage) and horticultural protocols (Fig. 1, see Harding et al. 2013) is needed before plants or seeds can be effectively conserved in ex situ institutions (Costa et al. 2017). Unfortunately, these data are still lacking for the vast majority of native species, let alone the threatened ones (Ribeiro et al. 2016). 
There are many challenges ahead that need to be urgently tackled if we are to steer the knowledge and conservation biases in the ex situ conservation of the Brazilian flora (Tab. 1). We need to reduce both the phylogenetic and geographic biases that permeate the knowledge on the seed ecology (Ribeiro et al. 2016). Reducing the phylogenetic bias means we need to conserve species in families other than Cactaceae, Bromeliaceae and Orchidaceae, which are the dominant in ex situ collections. Reducing the geographic bias means we need to safeguard threatened species from biomes other than the Atlantic Forest. As more species will become threatened in the near future (Pimm \& Raven 2017), and risk assessment is carried out for more species (G. Martinelli, personal communication), the task for the future is more challenging that it is today (Tab. 1).

Large parts of the country are covered by forests which typically harbor species with recalcitrant (desiccation-sensitive) seeds which cannot be stored by convenient methods (Walters et al. 2013; Wyse \& Dickie 2017). This implies we need to develop specific protocols for cryogenic storage (Tab. 1), especially for species from the Amazon and the Atlantic Forest.
We found different difficulties in identifying and contacting plant conservation institutions involved in conserving threatened plants. Another hurdle was to get detailed and organized information in a user-friendly and interactive manner. We urge authorities to urgently develop a national integrated database similar to that of PlantSearch by BGCI (<https://www.bgci.org/plant_search.php $>$ ). This database will contribute to the provision of organized information on plant species conserved in botanic gardens, national (i.e., EMBRAPA) and regional research companies and universities. Therefore, detailed information on ex situ conserved threatened plant species will be available for conservation, research and educational purposes. Ultimately, this database will be used to evaluate progress toward Target 8 of the GSPC, expanding the knowledge to save and understand plant diversity (Tab. 1).

We also need to develop protocols to evaluate germplasm quality (Liu et al. 2018) including accurate plant identification; genetic representativeness of the species; population and individual sampled; high viability with acceptable longevity; contain sufficient germplasm to supply intended uses; and collection acquired

Table 1 - Challenges and solutions to overcome hurdles in ex situ conservation in Brazil.

\begin{tabular}{|c|c|c|c|}
\hline Challenge & Why it is a problem & Proposed solutions & Reference \\
\hline Knowledge gap & $\begin{array}{l}\text { Prevents determination of the best } \\
\text { ex situ conservation method }\end{array}$ & $\begin{array}{l}\text { To use phylogenetic and functional information } \\
\text { to improve knowledge on relevant seed traits }\end{array}$ & $1,2,3$ \\
\hline $\begin{array}{l}\text { Phylogenetic and } \\
\text { geographic bias }\end{array}$ & $\begin{array}{l}\text { Restricts the evolutionary and } \\
\text { functional diversity of seed banks }\end{array}$ & $\begin{array}{l}\text { To sample species in undersampled } \\
\text { areas and clades }\end{array}$ & 1 \\
\hline $\begin{array}{l}\text { Increasing number } \\
\text { of threatened } \\
\text { species }\end{array}$ & $\begin{array}{l}\text { As more species are becoming } \\
\text { threatened, more species need } \\
\text { to be conserved }\end{array}$ & $\begin{array}{l}\text { To implement optimized protocols for seed } \\
\text { banking, change legislation to require ex situ } \\
\text { conservation before degrading endeavors }\end{array}$ & $4,5,6,7$ \\
\hline $\begin{array}{l}\text { Increase genetic } \\
\text { diversity }\end{array}$ & $\begin{array}{l}\text { Poor information on genetic } \\
\text { diversity in seed banks }\end{array}$ & $\begin{array}{l}\text { To established a genetically representative } \\
\text { ex situ collection }\end{array}$ & 8,9 \\
\hline $\begin{array}{l}\text { Increase availability } \\
\text { of seeds for } \\
\text { restoration }\end{array}$ & $\begin{array}{l}\text { Poor information available on } \\
\text { the restoration seed pool }\end{array}$ & $\begin{array}{l}\text { To bank higher number of seeds per population/ } \\
\text { species, prioritize species with higher potential for } \\
\text { restoration, implement seed production areas }\end{array}$ & $1,10,11$ \\
\hline $\begin{array}{l}\text { Conservation of } \\
\text { recalcitrant seeds }\end{array}$ & $\begin{array}{l}\text { Recalcitrant seeds are not amenable } \\
\text { to traditional seed storage methods }\end{array}$ & $\begin{array}{l}\text { To develop specific protocols for cryogenic } \\
\text { storage, in vitro slow growth }\end{array}$ & 12,13 \\
\hline $\begin{array}{l}\text { Data accessibility } \\
\text { and science } \\
\text { communication }\end{array}$ & $\begin{array}{l}\text { Knowledge is restricted to academics } \\
\text { and does not reach decision-makers }\end{array}$ & $\begin{array}{l}\text { To implement on-line platform, activities of } \\
\text { science outreach, and publications in Portuguese }\end{array}$ & 14,15 \\
\hline
\end{tabular}


with all consents and data to facilitate intended users. Unfortunately, most information regarding germplasm quality is not readily available in our database. Assessing germplasm quality is highly relevant for restoration purposes.

GSPC Target 8 does not consider the extent of habitats that a species occupies or how collections of a particular species should be representative of the genetic diversity of that species. Thus, the collections do not necessarily hold the associated provenance, ecological and conservation information associated to the species conserved, which is essential for successful recovery and restoration programs. Species-specific efforts to increase germplasm genetic diversity (Griffith et al. 2017) and sufficient material are critical for plant reintroduction and restoration (Tab. 1). Emerging technologies and protocols that optimize staff time and costs, and at the same time reduce the number of seeds for testing, should be implemented to monitor viability in seed genebanks and in tissue cultures (Harding et al. 2013; Davies et al. 2016; Hay \& Whitehouse 2017). Lastly, our nationwide survey has shown the need to improve data accessibility and science communication.

Brazil's progress in Target 8 can be improved if it learns from the international experience and follows the countries with more extensive work on ex situ conservation initiatives. For instance, the United States, France and Australia have a large number of institutions with seed banking and have strong national networks working together to conserve plant diversity (O'Donnell \& Sharrock 2017). In megadiverse countries, such as South Africa, a successful National Strategy for Plant Conservation has been accomplished where taxonomists, government agencies and nongovernmental organizations jointly coordinated seed banking of $35 \%$ of threatened species by 2013 (Sharrock et al. 2014). Mexico, in turn, proposes to conserve $100 \%$ of threatened species in botanic gardens by 2030 and $90 \%$ of them with propagation and cultivation programs.

No institution can effectively act alone in ex situ conservation, so integrating Brazilian institutions is major requirement that needs to be filled to promote cross-institution collaborative efforts. To strengthen the contribution of institutions to ex situ conservation, a national network should be established, under the steering of the MMA, as suggested by the National Center for Flora Conservation (CNCFlora) on National Strategy for ex situ conservation of threatened Brazilian
Flora (CNCFlora 2016). This network will increase conservation redundancy across institutions and secure against lost of accessions, especially for critically endangered species.

In 2011, Australia launched the Seed Bank Partnership and "The 1,000 species project" from a collaborative national effort to bank seeds of $80 \%$ of Australian threatened flora by 2020 (CHABG 2011). Overall, Australia and New Zealand had already banked $56 \%$ of threatened species by 2013 (Sharrock et al. 2014). China established the Germplasm Bank of Wild Species in 2008 from a nationwide seed-collecting network that includes 71 research institutions to store 10,000 national species in seed banks by $2020 ; 8,855$ species were successfully banked by 2014, which represents about $30 \%$ of the country's vascular plant diversity (Cai 2015). The Mexican National Strategy for Plant Conservation embraces 22 action groups that, by 2012, had coordinated long-term seed conservation for 1,174 species (León-Lobos et al. 2012). Seeds of Success and the US Center for Plant Conservation are native seed collection programs coordinated by multiple USDA Agricultural Research Service seed storage facilities and partner institutions to collect threatened species and develop ecological restoration initiatives in the United States (Galbraith \& Kennedy 2006; Haidet \& Olwell 2015). In Europe, the European Native Seed Conservation Network (ENSCONET) operated during 2005-2009 and updated an ENSCONET Consortium in 2010, which had included $63 \%$ of threatened species in seed banks and 48\% available for restoration programs by the end of 2016 (Rivière \& Müller 2017).

Monitoring progress towards Target 8 at a global scale has previously been problematic due to the limited information on which species are being conserved, where, and which of these are threatened (O’Donnell \& Sharrock 2017). Some countries have this information at the national level, however for megadiverse countries with a high number of threatened species and a lack of resources, Target 8 is an ambitious task. Therefore, implementing and integrating information in a national platform and contribute data to BGCI PlantSearch is of vital importance.

Resources also need to be secured to improve new collections with a design that maximizes genetic diversity and to develop and implement an ex situ conservation management plan for the species. Management plans include periodic assessment of seed viability, assessment of genetic diversity, acquisition of new material, 
distribution to other institutions as backups and working with partners to use stored material for in situ conservation efforts, such as restoration programs (Fant et al. 2016).

Some opportunities for obtaining financial resources are emerging for the coming years. Considering the Brazilian Biodiversity Law (Law 13,123 - May 20, 2015), the Federal government will be the main beneficiary of benefit-sharing. MMA will be able to negotiate the benefit-sharing and, possibly, to indicate projects aligned with its interests of biodiversity conservation. Additionally, the recently-created PLANAVEG - National Plan for Native Vegetation Recovery (Law 8,972 January 23, 2017) aims to expand and strengthen public policies, financial incentives, markets, good agricultural practices and other measures necessary for the recovery of native vegetation of 12 million hectares by 2030 . Target 8 can be strengthened by this plan when threatened species (at least $20 \%$ of threatened species) are indicated for vegetation recovery and restoration programs. The demand for propagules (seeds, cuttings, etc.) of threatened species can reinforce ex situ conservation actions. We strongly suggest that the fund-raising by the MMA together with the benefits-sharing actions should also be aimed to support projects related to biodiversity conservation, mainly for ex situ conservation of threatened flora. Finally, we also propose that the development of other financial incentives, such as monetary environmental compensation and the payment for environmental services can be conducted to reintroduction projects with threatened species.

Below we propose a strategy for GSPC targets in 2020-2030. If Brazil is to advance in ex situ conservation, the actions below are strictly needed:

- To develop a national strategic framework to improve the ex situ conservation of threatened species;

- To identify priorities species and research priorities to improve the knowledge of threatened species;

- To expand the capacity and delivery of ex situ conservation as part of an integrated conservation approach to improve the effectiveness of threatened plant conservation and ecological restoration;

- To expand professional capacity for ex situ conservation through recruitment and specialist training;

- To develop a national information database for ex situ conservation;
- To establish a national network to enhance ex situ conservation of the threatened Flora;

- To improve the national infrastructure of seed banks;

- To establish at least one well-structured seed bank for each region of the country;

- To maintain ex situ collections that meet physiological, genetic and sanitary criteria of quality;

- To develop protocols for propagation, cultivation and reintroduction for threatened Brazilian Flora;

- To adopt threatened species as symbols in awareness campaigns about the need for plant conservation;

- To create mechanisms and incentives to include educational and research institutions, botanic gardens, agricultural and environmental agencies in the conservation efforts of threatened species;

Given the huge challenges for associated with the study of seed storage and cultivation of native species, Target 8 is unachievable by 2020 . Therefore, we suggest the revised Target for 2020 2030 to call for at least 50 percent of threatened plant species to be included in ex situ collections, preferably in the country of origin, and at least 5 percent available for recovery and restoration programs. Such strategy is similar to that adopted by megadiverse South Africa, providing a more realistic scenario (Sharrock et al. 2014). We also recommend the development of an on-line database and protocols to assess germplasm quality and monitoring, so that ex situ conservation can be integrated with in situ strategies.

\section{Acknowledgments}

We thank all respondents to our poll and all institutions who responded with our requests. A.L.T. and M.Z. received a Post-graduate scholarship from CAPES. F.A.O.S. received a Productivity grant from CNPq and FAPEMIG.

\section{References}

Amano T, González-Varo JP \& Sutherland W (2016) Languages are still a major barrier to global science. PLoS Biology 14: e2000933.

Brasil - Ministério do Meio Ambiente (2014) Portaria MMA n ${ }^{\circ} 443$ de 17 de dezembro de 2014. Diário Oficial da União de 18 de dezembro de 2014, $\mathrm{n}^{\circ}$ 245, Seção 1, Brasília. Pp. 110-121.

Broadhurst L, Hopley T, Li L \& Begley J (2017) A genetic assessment of seed production areas 
(SPAs) for restoration. Conservation Genetics 18: 1257-1266.

Cai J (2015) Seed conservation of China's flora through the germplasm bank of wild species. BGJournal 12: 22-24.

CBD (2010) Conference of the Parties 10 Decision X/17. Consolidated update of the Global Strategy for Plant Conservation 2011-2020. Convention on Biological Diversity, Nagoya. 13p.

CHABG (2011) Safeguarding Australia's flora through a national network of native plant seed banks: business plan 2011-2020. The Council of Heads of Australian Botanic Gardens Inc., Canberra. 23p.

Costa MLMN, Wyse JP, Fernandes RA \& Peixoto AL (2018) Conservation of threatened plant species in botanic garden reserves in Brazil. Oryx 52: 108-115.

Costa MLMN, Maunder M, Pereira TS \& Peixoto AL (2017) Brazilian botanic gardens: an assessment of conservation capacity. Sibbaldia 14: 97-117.

CNCFLORA (2016) Estratégia nacional para conservação ex situ de espécies ameaçadas da flora brasileira. CNCFlora - Centro Nacional de Conservação da Flora. Instituto de Pesquisas Jardim Botânico do Rio de Janeiro, Rio de Janeiro. 24p.

Cochrane JA, Crawford AD \& Monks LT (2007) The significance of ex situ conservation to reintroduction of threatened plants. Australian Journal of Botany 55: 356-361.

Crouzeilles R, Feltran-Barbieri R, Ferreira MS \& Strassburg BB (2017) Hard times for the Brazilian environment. Nature Ecology and Evolution 1: 1213.

Davies RM, Newton RJ, Hay FR \& Probert RJ (2016) 150 - seed comparative longevity protocol - a reduced seed number screening method for identifying short - lived seed conservation collections. Seed Science and Technology 44: 569-584.

Doubleday ZA \& Connell SD (2017) Publishing with objective charisma: breaking science's paradox. Trends in Ecology and Evolution 32: 803-805.

Fant JB, Havens K, Kramer AT, Walsh SK, Callicrate T, Lacy RC, Maunder M, Meyer AH \& Smith PP (2016) What to do when we can't bank on seeds: what botanic gardens can learn from the zoo community about conserving plants in living collections. American Journal of Botany 103: 1-3.

Flora do Brasil 2020 em construção. Instituto de Pesquisas Jardim Botânico do Rio de Janeiro. Available at $<$ http://floradobrasil.jbrj.gov.br/>. Access on 18 dezembro 2017.

Forzza RC, Baumgratz JFA, Bicudo CEM, Canhos DA, Carvalho AA, Coelho MAN, Costa AF, Costa DP, Hopkins MG, Leitman PM, Lohmann LG, Lughadha EN, Maia LC, Martinelli G, Menezes M, Morim MP, Peixoto AL, Pirani JR, Prado J, Queiroz LP, Souza S, Souza VC, Stehmann JR, Sylvestre LS, Walter BMT \& Zappi DC (2012) New Brazilian floristic list highlights conservation challenges. Bioscience
62: $39-45$.

Galbraith D \& Kennedy K (2006) The development of a strategic plan for a regional network of botanic gardens for conservation: the North American experience. BGjournal 3: 8-10.

Griffith MP, Calonje M, Meerow AW, Francisco-Ortega J, Knowles L, Aguilar R, Tut F, Sánchez V, Meyer A, Noblick LR \& Magellan TM (2017) Will the same ex situ protocols give similar results for closely related species? Biodiversity and Conservation 26: 2951-2966.

Guerrant EO, Havens K \& Maunder M (2004) Ex situ plant conservation: supporting species survival in the wild. Island Press, Washington, DC. 504p.

Haidet M \& Olwell P (2015) Seeds of success: a national seed banking program working to achieve longterm conservation goals. Natural Areas Journal 35: 165-173.

Harding K, Benson EE, Nunes EC, Pilatti FK, Lemos J \& Viana AM (2013) Can biospecimen science expedite the ex situ conservation of plants in megadiverse countries? A focus on the flora of Brazil. Critical Reviews in Plant Science 32: 411-444.

Hawkes JG, Maxted N \& Ford-Lloyd BV (2000). The ex situ conservation of plant genetic resources. Kluwer, Dordrecht. 250p.

Hay FR \& Whitehouse KJ (2017) Rethinking the approach to viability monitoring in seed genebanks. Conservation Physiology 5: cox009. DOI: 10.1093/ conphys/cox009

Heywood VH (2017) Plant conservation in the Anthropocene - challenges and future prospects. Plant Diversity 39: 314-330.

Joppa LN, Visconti P, Jenkins CN \& Pimm SL (2013) Achieving the convention on biological diversity's goals for plant conservation. Science 341: 1100-1103.

Ladouceur E, Jiménez-Alfaro B, Marin M, de Vitis M, Abbandonato H, Iannetta PPM, Bonomi C \& Pritchard HW (2017) Native seed supply and the restoration species pool. Conservation Letters 11: e12381.

León-Lobos P, Wayc M, Arandad PD \& Lima-Junior M (2012) The role of ex situ seed banks in the conservation of plant diversity and in ecological restoration in Latin America. Plant Ecology and Diversity 5: 245-258.

Li DZ \& Pritchard HW (2009) The science and economics of ex situ plant conservation. Trends in Plant Science 14: 614-21.

Liu U, Breman E, Cossu TA \& Kenney S (2018) The conservation value of germplasm stored at Millennium Seed Bank, Royal Botanic Gardens, Kew, UK. Biodiversity and Conservation 27: 13471386.

Mounce R, Smith P \& Brockington S (2017) Ex situ conservation of plant diversity in the world's botanic gardens. Nature Plants 3: 795-802. 
O’Donnell K \& Sharrock S (2017) The contribution of botanic gardens to ex situ conservation through seed banking. Plant Diversity 39: 373-378.

Oldfield SF (2009) Botanic gardens and the conservation of tree species. Trends in Plant Science 14: 581-583.

Pelissari F, Jose AC, Fontes MAL, Matos ACB, Pereira WVS \& Faria JMS (2018) A probabilistic model for tropical tree seed desiccation tolerance and storage classification. New Forests 49: 143-158.

Pellegrini PA \& Balatti GE (2016) Noah's arks in the XXI century. A typology of seed banks. Biodiversity and Conservation 25: 2753-2769.

Pimm SL \& Raven PH (2017) The fate of the world's plants. Trends in Ecology \& Evolution 32: 317-320.

Ribeiro GVT, Teixido AL, Barbosa NPU \& Silveira, FAO (2016) Assessing bias and knowledge gaps on seed ecology research: implications for conservation agenda and policy. Ecological Applications 26: 2033-2043.

Rivière S \& Müller J (2017) Contribution of seed banks across Europe towards the 2020 Global Strategy for Plant Conservation targets, assessed through the ENSCONET database. Oryx 52: 464-470.

Scarano F, Guimarães A \& da Silva JM (2012) Rio+20: lead by example. Nature 486: 25-26.

Sharrock S, Oldfield S \& Wilson O (2014) Plant Conservation Report 2014: a review of progress in implementation of the Global Strategy for Plant Conservation 2011-2020. CBD, Montréal, and BGCI, Richmond. 58p.

Teixido AL, Toorop PE, Liu U, Ribeiro GV, Fuzessy LF, Guerra TJ \& Silveira FAO (2017) Gaps in seed banking are compromising the GSPC's Target 8 in a megadiverse country. Biodiversity and Conservation 26: 703-716.

Thormann I, Dulloo M \& Engels J (2006) Techniques for ex situ plant conservation. In: Henry RJ (ed.) Plant conservation genetics. The Haworth Press, New York. Pp 7-36. DOI: 10.1300/5546 02

UNCED (1992) Convention on biological diversity. United Nations Conference on Environment and Development, Geneva. 351p.

Volis S (2017) Conservation utility of botanic garden living collections: setting a strategy and appropriate methodology. Plant Diversity 39: 365-372. DOI: 10.1016/j.pld.2017.11.006

Walters C, Berjak P, Pammenter N, Kennedy K \& Raven P (2013) Preservation of recalcitrant seeds. Science 339: 915-916.

Watson JEM \& Venter O (2017) A global plan for nature conservation. Nature 550: 48-49.

Wyse SV \& Dickie JB (2017) Predicting the global incidence of seed desiccation sensitivity. Journal of Ecology 105: 1082-1093. 